\title{
EFFECT OF PRIOR MARTENSITE ON MECHANICAL PROPERTIES OF AUSTEMPERED DUCTILE IRON
}

\author{
$\mathrm{CHEN}_{\text {YANG }}{ }^{1}$, DEREK O. NORTHWOOD ${ }^{2} \& \mathrm{CHENG}^{2} \mathrm{LIU}^{1}$ \\ ${ }^{1}$ College of Mechanical Engineering, Yangzhou University, PR China. \\ ${ }^{2}$ Department of Mechanical, Automotive and Materials Engineering, University of Windsor, Canada.
}

\begin{abstract}
An unalloyed ductile iron, which incorporates $\mathrm{C}$ and $\mathrm{Si}$ as major and $\mathrm{Mn}$ as minor alloying elements, is processed by a novel austempering process, in order to obtain superior mechanical properties. The samples are initially austenitized at $890^{\circ} \mathrm{C}$ for $20 \mathrm{~min}$, then quenched into patented water-based quenching liquid at $180^{\circ} \mathrm{C}$ for $0.5,2$ and $3.5 \mathrm{~s}$ respectively, and austempered at $220^{\circ} \mathrm{C}$ for $240 \mathrm{~min}$ in an electric furnace. Optical microscopy (OM) and scanning electron microscopy (SEM) are performed to correlate the mechanical properties with microstructural characteristics. It is found that partial martensite can be formed firstly upon quenching, which will accelerate the subsequent bainitic transformation and promote refinement of multiphase colonies during austempering. The prior martensite content increases with increasing holding time during quenching. A tensile strength of $1330 \mathrm{MPa}$, an elongation of $3.13 \%$ and a hardness of $45 \mathrm{HRC}$ can be achieved by controlling the prior martensite content to $12 \%$. SEM of fracture surfaces reveals a mixed ductile and cleavage rupture morphology type in all samples. The results indicate that the tensile behavior of the investigated ADI is mainly influenced by the content of prior martensite. Keywords: austempering process, bainitic transformation, prior martensite, tensile strength.
\end{abstract}

\section{INTRODUCTION}

Austempered ductile iron (ADI) is an attractive material for industrial applications due to its good mechanical properties. However, a higher strength and hardness, as well as substantial ductility and toughness, is required for ADI to substitute for steel in certain applications such as automotive carburized gears and rails.

It is well known that the austempering process is of importance in determining the specific microstructures and properties of ADI [1-5]. The common austempering process for ADI starts with austenitizing in the range of $840^{\circ} \mathrm{C}$ and $950^{\circ} \mathrm{C}$, then rapidly quenching to an intermediate temperature usually between $250^{\circ} \mathrm{C}$ and $450^{\circ} \mathrm{C}$, and subsequently isothermal austempering for a certain time, followed by final cooling to room temperature [6-12]. This produces a microstructure consisting of bainitic ferrite $(\mathrm{BF})$ and high-carbon retained austenite (RA) with graphite nodules (GN) dispersed in the matrix. However, many studies have suggested that it is difficult to obtain both high strength and high toughness in a single austempering process. Therefore, it is necessary to develop the process technology for a high-performance ADI product.

A novel two-step austempering process for ADI at a lower temperature of $220^{\circ} \mathrm{C}$, which is almost the lowest austempering temperature from the open literature, is designed to form a multiphase structure for improving the mechanical properties of ADI in this paper. The transformation mechanism during austempering at lower temperature is also discussed. Special attention is paid to the effect of prior martensite on the austempering process and the mechanical properties of ADI.

\section{EXPERIMENTAL PROCEDURE}

An unalloyed ductile cast iron was produced in a commercial electric induction furnace. The melt was poured into standard 25.4 mm ' $Y$ ' block shaped sand mold (ASTM A-395) (see Fig.1). 
Table 1: Chemical composition of the ductile cast iron (wt.\%).

\begin{tabular}{lllll}
\hline $\mathrm{C}$ & $\mathrm{Si}$ & $\mathrm{Mn}$ & $\mathrm{P}$ & $\mathrm{S}$ \\
\hline 3.5 & 2.5 & 0.2 & $<0.0015$ & $<0.0015$ \\
\hline
\end{tabular}

The chemical composition of the ductile iron is given in Table 1 . After austenitizing at $890^{\circ} \mathrm{C}$ for $20 \mathrm{~min}$ in a JK-SX2-10-12N electric furnace, the samples were rapidly quenched to $180^{\circ} \mathrm{C}$ by controlling the patented water-based quenching liquid for 0.5 (sample A), 2 (sample B) and $3.5 \mathrm{~s}$ (sample C) respectively, then austempered at $220^{\circ} \mathrm{C}$ for $240 \mathrm{~min}$ in another electric furnace, and finally cooled in air.

Tensile samples were machined in accordance with ASTM standard E8M from the ' $\mathrm{Y}$ ' blocks using a spark machine (electric discharge machining) (see Fig. 1). The tensile tests were performed using a DNS100 universal testing machine, with a $100 \mathrm{kN}$ load at a crosshead speed of $0.05 \mathrm{~mm} / \mathrm{min}$. Hardness tests were carried out using a HBE-3000 Brinell hardness tester with a load of $750 \mathrm{~kg}$. For each sample condition, three readings were taken and averaged to represent the hardness value.

After being ground, polished and etched in $2 \%$ nital solution, the microstructure of each sample was observed using optical microscopy (LEICA GQ-300). The fracture surfaces of the tensile samples were examined in a XL30-ESEM scanning electron microscope. Imagepro plus 6.0 software was used to quantitatively evaluate the microstructure.

\section{RESULTS AND DISCUSSION}

Figure 2a shows a typical optical micrograph of the as-cast ductile iron sample, with nodules of graphite in a matrix, which is a mixture of fine pearlite and ferrite (see Fig. 2b).The OM

(a)

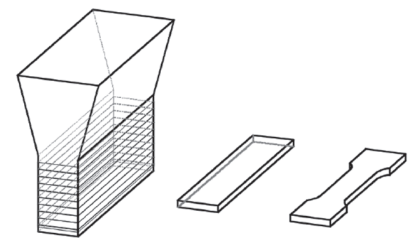

(b)

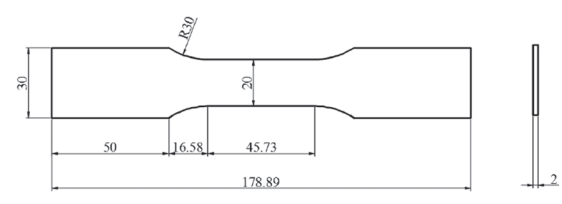

Figure 1: Schematics of (a) samples machined from Y blocks; (b) tensile test samples.
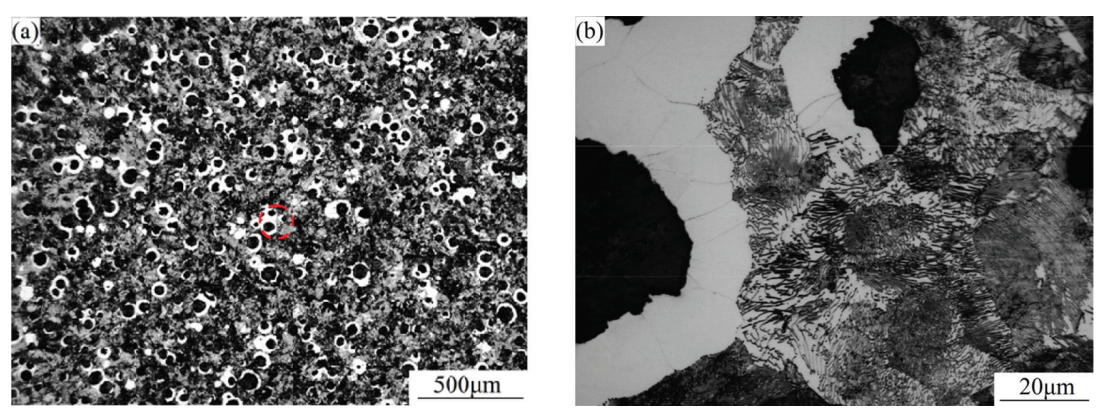

Figure 2: OM micrographs of (a) as-cast ductile iron; (b) magnified area of red dash circle in (a). 

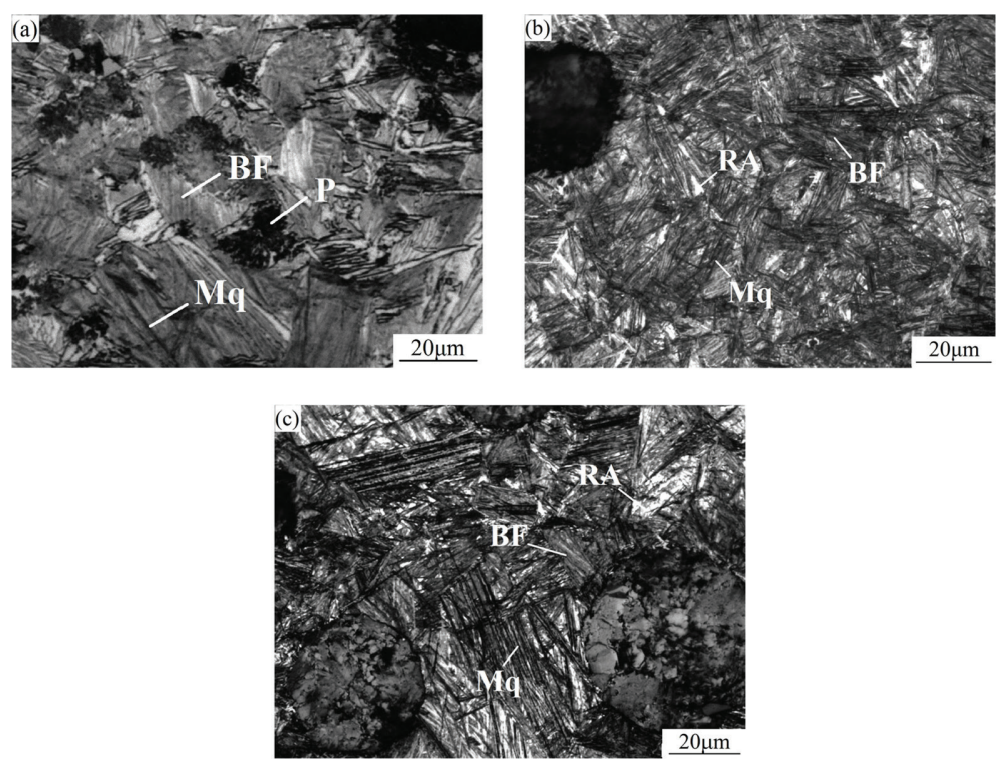

Figure 3: OM micrographs of (a) sample A; (b) sample B; (c) sample C.

micrographs in Fig. 3 show that the matrix after austempering contains three main constituents, including BF (grey), RA (white) and needle-like prior martensite (Mq, dark black) in all samples. This is different from the normal ADI where the microstructure only consists of BF and RA. With increasing holding time during quenching, the amount of Mq increases (see from Fig. 3a and c) and the BF needle becomes much finer. Table 2 summarises the volume fraction of $\mathrm{Mq}$ obtained from the various austempering processes. With increasing holding time during quenching, the Mq content increases.

Figure 4 illustrates the influence of volume fraction of prior martensite on the mechanical properties of the samples. The tensile strength increases as the Mq content increases from 3 to $12 \%$ and drops with further increases to $29 \%$ in Mq content. The elongation has the same trend of change with increasing volume fraction of Mq. The optimum combination of tensile strength and elongation can be achieved at $12 \%$ volume fraction of $\mathrm{Mq}$ in sample B. Compared with as-cast ductile iron, each of three samples has a higher hardness value after austempering (Table 3). However, the hardness increases with increasing holding time during quenching from $0.5 \mathrm{~s}$ in sample A to $3.5 \mathrm{~s}$ in sample $\mathrm{C}$.

The designed austempering process in this paper consists of initially rapid quenching and finally austempering at low temperature. In the process of rapid quenching, it is not surprising that a certain amount of $\mathrm{Mq}$ is formed during quenching to $180^{\circ} \mathrm{C}$ (see Fig. 3) since the start temperature of the martensite formation (Ms) is approximately $220^{\circ} \mathrm{C}$ according to the calculation formula given in Ref. [13]. On quenching to $180^{\circ} \mathrm{C}$ for a short time of $0.5 \mathrm{~s}$, the temperature in a few local areas of the sample can reach this temperature,

Table 2: Volume fraction of Mq of sample (\%).

\begin{tabular}{lll}
\hline Sample A & Sample B & Sample C \\
\hline $3 \pm 0.6$ & $12 \pm 0.9$ & $29 \pm 1.4$ \\
\hline
\end{tabular}




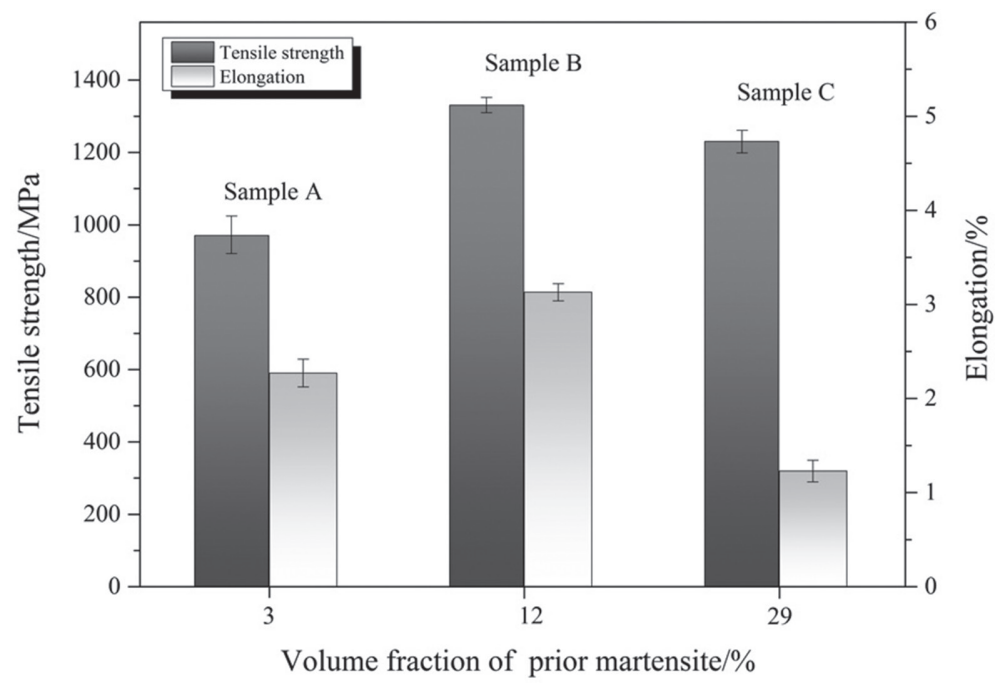

Figure 4: Influence of volume fraction of Mq on tensile strength and elongation.

Table 3: Hardness values of samples

\begin{tabular}{lllll}
\hline & As-cast ductile iron & Sample A & Sample B & Sample C \\
\hline Hardness/HB & $203 \pm 1.8$ & $370 \pm 1.4$ & $422 \pm 2.2$ & $464 \pm 1.6$ \\
Hardness/HRC $^{*}$ & $17 \pm 0.1$ & $40 \pm 0.1$ & $45 \pm 0.2$ & $50 \pm 0.1$ \\
\hline
\end{tabular}

*by conversion

which is lower than Ms point, thus only about 3\% Mq can be detected. After a longer holding time during quenching, the amount of $\mathrm{Mq}$ is increased to $29 \%$ since the martensite transformation can occur in more local areas of sample $\mathrm{C}$ during quenching (see Fig. 3 and Table 2).

The carbon concentration of RA is an important factor in determining the mechanical properties of ADI [14-18]. In the process of austempering at $220^{\circ} \mathrm{C}$ for $240 \mathrm{~min}$, the untransformed austenite during the initial quenching process will transform to $\mathrm{BF}$, and $\mathrm{Mq}$ will become carbon depleted martensite rather than conventional tempered martensite [19]. The high content Si can suppress cementite precipitation in the ductile iron. The excess carbon from supersaturated martensite migrates to the adjacent untransformed austenite during austempering at $220^{\circ} \mathrm{C}$ (above Ms), which can enrich and retain austenite, instead of forming quenched martensite with high carbon content at room temperature upon final quenching. It can be seen from Fig. 5 that a multiphase structure of Mq surrounded by fine $\mathrm{BF}$ and film austenite with the thickness less than $100 \mathrm{~nm}$ is formed in sample B after austempering at $220^{\circ} \mathrm{C}$ for $240 \mathrm{~min}$. This result is consistent with the literatures, and such a microstructure is claimed to exhibit excellent mechanical properties [20,21]. This suggests that the $\mathrm{Mq}$ can accelerate the subsequent nanobainitic transformation due to the similar orientation between Mq and adjacent BF needles. For the formation of Mq, dislocations with a high density in the austenite near Mq lath boundary are introduced to increase the nucleation rate of $\mathrm{BF}$ and thus refine the microstructure [21, 22]. When the Mq content increases from $3 \%$ (sample A in Fig. 4) to 12\% (sample B in Fig. 4), more fine multiphase structures can be formed, which leads to a better combination of strength and elongation. 


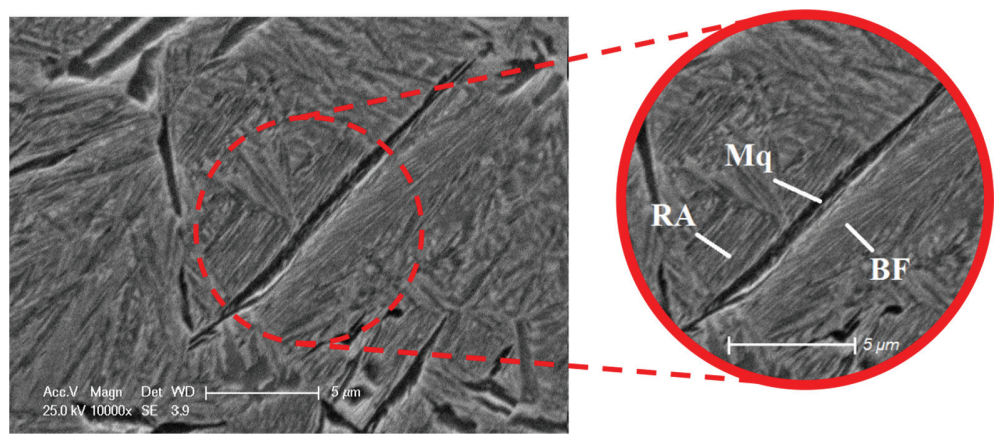

Figure 5: SEM micrograph of sample B austempered at $220^{\circ} \mathrm{C}$ for $240 \mathrm{~min}$.
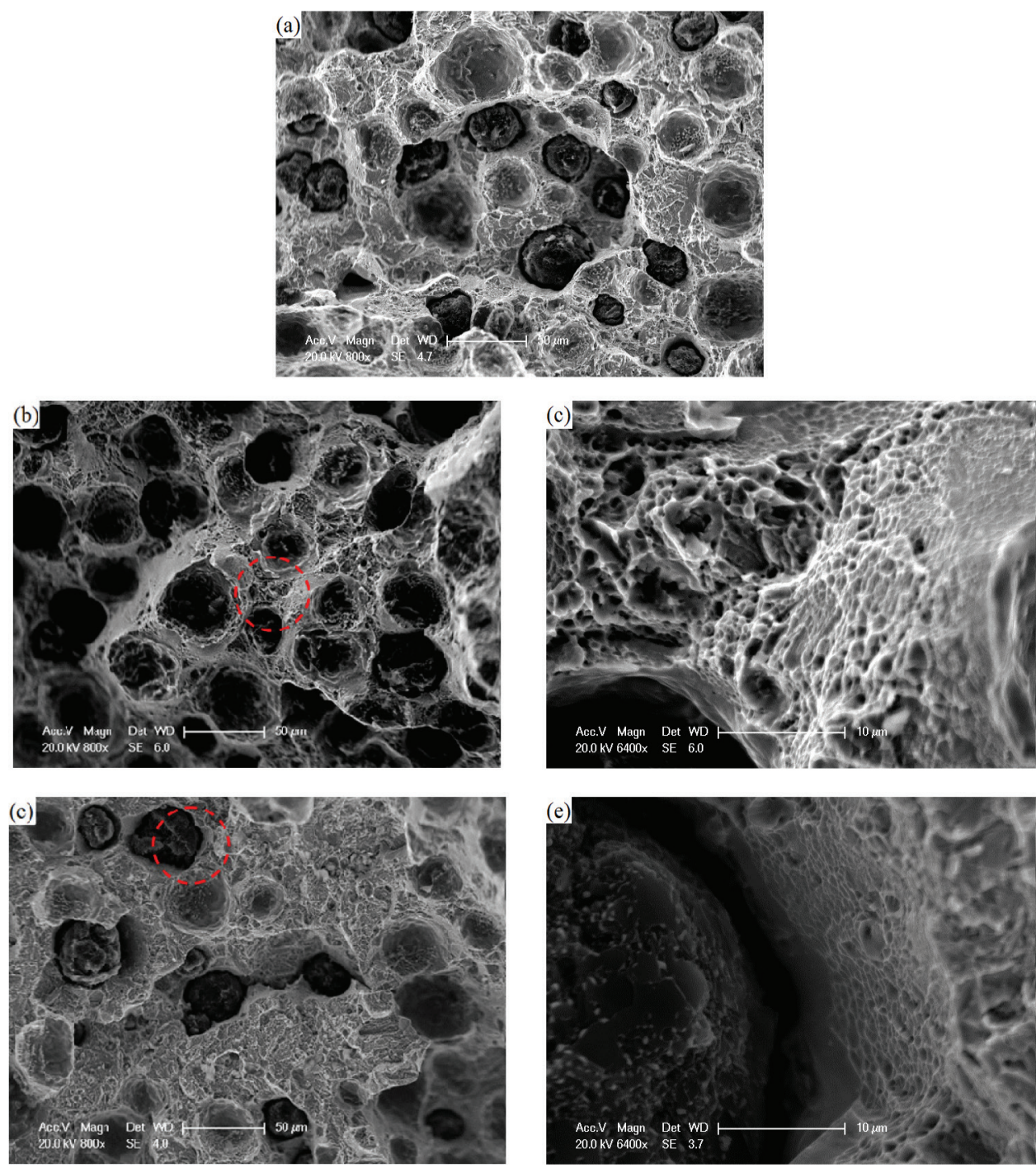

Figure 6: SEM fractographs of (a) sample A; (b) sample B; (c) area marked by red dash circle in Fig. 6b, d sample C; (e) area marked by red dash circle in Fig. d. 
Figure 4 shows that both the tensile strength and elongation decrease with increasing $\mathrm{Mq}$ content from $12 \%$ (sample B in Fig. 4) to $29 \%$ (sample C in Fig. 4). This corresponds to a relative reduction in the amount of multiphase structure with the increased amount of Mq.

Generally, the hardness increases as the martensite content increases [23]. Thus, the reason why the hardness value increases with increasing holding time during quenching, might be explained by the amount of Mq (see Table 3).

Typical SEM fractographs for the samples after tensile testing are shown in Fig. 6. For sample A with $3 \% \mathrm{Mq}$, the fracture is a cleavage type (see Fig. 6a). For sample B with $12 \%$ $\mathrm{Mq}$, there are a large amount of dimples and some cleavage facets (see Fig. $6 \mathrm{~b}$ and c). When the amount of $\mathrm{Mq}$ is increased to $29 \%$ in sample $\mathrm{C}$, there is a mixture of ductile and cleavage fracture mechanism (see Fig. 6d). Figure 6e indicates that less microductility can be found at the pull-out area of graphite nodule. Fracture observations support the tensile experimental results. Thus, sample B with $12 \% \mathrm{Mq}$ displays a mostly ductile fracture.

\section{CONCLUSIONS}

The tensile behavior of a ductile iron treated by a novel austempering process is evaluated. The designed austempering treatment consists of initial rapid quenching to $180^{\circ} \mathrm{C}$ for different times and finally austempering at $220^{\circ} \mathrm{C}$ for $240 \mathrm{~min}$. A multiphase structure of prior martensite and fine lath bainitic ferrite with a film retained austenite is obtained. The optimum mechanical properties, with a tensile strength of $1330 \mathrm{MPa}$ and an elongation of $3.1 \%$ can be achieved by controlling the prior martensite content to $12 \%$. This is mainly attributed to prior marteniste, which can accelerate the subsequent bainitic transformation and promote refinement of multiphase colonies.

\section{ACKNOWLEDGEMENTS}

The authors are grateful to Scientific Research Fund of Yangzhou University for their financial support (project code 20160357) and also to the Testing Center of Yangzhou University.

\section{REFERENCES}

[1] Harding, R.A., The production, properties and automotive applications of austempered ductile iron. Metals and Materials, 45(1), pp. 1-16, 2007.

[2] Zhang, N., Zhang, J.W., Lu, L.T., Zhang, M.T., Zeng, D.F. \& Song, Q.P., Wear and friction behavior of austempered ductile iron as railway wheel material. Materials \& Design, 89, pp. 815-822, 2015.

https://doi.org/10.1016/j.matdes.2015.10.037

[3] Dong, J.L., Ju, F.C., Chen, H.S. \& Chen, L.W., Influence of austempering temperature on fracture toughness in bainitic nodular cast iron. Journal of Materials Science Letters, 5(5), pp. 555-558, 1986. https://doi.org/10.1007/BF01728689

[4] Yang C., Cui, X.X., Zhao, Z.B., Hua, G. \& Liu, C., Role of bulky retained austenite in austempered ductile iron. Advanced Materials Research, 1142, pp. 19-22, 2016. https://doi.org/10.4028/www.scientific.net/AMR.1142.19

[5] Garin, J.L. \& Mannheim, R.L., Strain-induced martensite in ADI alloys. Journal of Materials Processing Technology, 143-144(1), pp. 347-351, 2003. https://doi.org/10.1016/S0924-0136(03)00452-7 
[6] Panneerselvam, S., Martis, C.J., Putatunda, S.K. \& Boileau, J.M., An investigation on the stability of austenite in austempered ductile cast iron (ADI). Materials Science \& Engineering A, 626(7), pp. 237-246, 2015. https://doi.org/10.1016/j.msea.2014.12.038

[7] Sohi, M.H., Ahmadabadi, M.N. \& Vahdat, A.B., The role of austempering parameters on the structure and mechanical properties of heavy section ADI. Journal of Materials Processing Technology, 153(1), pp. 203-208, 2004. https://doi.org/10.1016/j.jmatprotec.2004.04.308

[8] Ahmadabadi, M.N., Ghasemi, H.M. \& Osia, M., Effects of successive austempering on the tribological behavior of ductile cast iron. Wear, 231(2), pp. 293-300, 1999. https://doi.org/10.1016/S0043-1648(99)00163-5

[9] Toktaş, G.M., Tayanç, M. \& Toktaş, A., Effect of matrix structure on the impact properties of an alloyed ductile iron. Materials Characterization, 57(4-5), pp. 290-299, 2006. https://doi.org/10.1016/j.matchar.2006.02.008

[10] Hamid Ali, A.S. \& Elliot, R., Austempering of a Mn-Mo-Cu alloyed ductile iron part1austempering kinetics and processing windows. Materials Science and Technology, 12(12), pp. 1021-1031, 1996. https://doi.org/10.1179/mst.1996.12.8.679

[11] Putatunda, S.K., Singh, I. \& Bartosiewicz, L., Influence of chromium on mechanical properties of austempered ductile cast iron. Journal of Materials Engineering and Performance, 4(1), pp. 90-101, 1995. https://doi.org/10.1007/BF02682710

[12] Toktaş, G., Tayanç, M. \& Toktaş, A., Effect of matrix structure on the impact properties of an alloyed ductile iron. Materials Characterization, 57(4-5), pp. 290-299, 2006. https://doi.org/10.1016/j.matchar.2006.02.008

[13] Mallia, J., Grech, M. \& Smallman, R.E., Effect of silicon content on transformation kinetics of austempered ductile iron. Materials Science and Technology, 14(5), pp. 452-460, 1998.

https://doi.org/10.1179/mst.1998.14.5.452

[14] Hsu, C.H. \& Lin, K.T., A study on microstructure and toughness of copper alloyed and austempered ductile irons. Materials Science \& Engineering A, 528(18), pp. 5706-5712, 2011. https://doi.org/10.1016/j.msea.2011.04.035

[15] Balos, S., Radisavljevic, I., Rajnovic, D., Tabakovic, S., Cekic, O.E. \& Sidjanin, L., Geometry, mechanical and ballistic properties of ADI material perforated plates. Materials \& Design, 83, pp. 66-74, 2015. https://doi.org/10.1016/j.matdes.2015.05.081

[16] Bayati, H. \& Elliott, R., A stepped austempering heat treatment for a Mn alloyed ductile cast iron. Advanced Materials Research, 4-5, pp. 399-406, 1997. https://doi.org/10.4028/www.scientific.net/AMR.4-5.399

[17] Putatunda, S.K., Development of austempered ductile cast iron (ADI) with simultaneous high yield strength and fracture toughness by a novel two-step austempering process. Materials Science \& Engineering A, 315(1), pp. 70-80, 2001. https://doi.org/10.1016/S0921-5093(01)01210-2 
[18] Putatunda, S.K., Comparison of the mechanical properties of austempered ductile cast iron (ADI) processed by conventional and step-down austempering process. Materials and Manufacturing Processes, 25(8), pp. 749-757, 2010. https://doi.org/10.1080/10426910903367394

[19] Darwish, N. \& Eliott R., Austempering of low manganese ductile irons part 3 variation of mechanical properties with heat treatment conditions. Materials Science and Technology, 9(10), pp. 572-585, 1993.

https://doi.org/10.1179/mst.1993.9.10.882

[20] Liu, C., Yang, C., Cui, X.X., Zhao, Z.B. \& Hua, G., Bending property of ductile cast iron by a novel austempering. Transactions of Materials and Heat Treatment, 37, pp. 22-25, 2016. (In Chinese)

[21] Liu, C., Zhao, Z.B. \& Bhole, S.D., Lathlike upper bainite in a silicon steel. Materials Science \& Engineering A, 434(1-2), pp. 289-293, 2006.

https://doi.org/10.1016/j.msea.2006.06.078

[22] Gong, W., Tomota, Y., Harjo, S., Sua, Y.H. \& Aizawaa, K., Effect of prior martensite on bainite transformation in nanobainite steel. Acta Materialia, 85, pp. 243-249, 2015. https://doi.org/10.1016/j.actamat.2014.11.029

[23] Stokes B., Gao, N. \& Reed, P.A.S., Effect of graphite nodules on crack growth behavior of austempered ductile iron. Materials Science and Engineering A, 445-446(6), pp. 374-385, 2007.

https://doi.org/10.1016/j.msea.2006.09.058 